\title{
Series editor's foreword
}

Christoph Menke is one of the leading figures in the current generation of Frankfurt School critical theorists. His work on aesthetics in The Sovereignty of Art (1998), Tragic Play (2009), Force: A Fundamental Concept of Aesthetic Anthropology (2012) and Die Kraft der Kunst (2013) marks a fundamental philosophical renewal of critical theory's engagement with this area of enquiry, while he has also made important and distinctive contributions to moral, legal, and political philosophy in works such as Tragödie im Sittlichen: Gerechtigkeit und Freiheit nach Hegel (1996), Reflections of Equality (2006), and Kritik der Rechte (2015). The essay "Law and Violence" presented in this volume exemplifies the character of his engagement with central topics of legal and political philosophy, and in particular his use of the analysis of literary texts as a medium for illuminating philosophical problems. Menke's work stands within the tradition of thinkers such as Adorno and Cavell, for whom attention to artistic works (for example, in music or film or drama) provides a way of both widening and focusing reflection on philosophical predicaments that express constitutive features of our practical condition.

The essay "Law and Violence" can be seen as developing themes from Menke's earlier work in Reflections of Equality addressing the relationship between equality and individuality as one of perpetual strife, and in Tragic Play analyzing the ironic character of tragedy. In this work, however, the focus is on the paradoxical character of law and specifically concerns the structural violence of law as the political imposition of normative order onto a "lawless" condition. The paradox of law which grounds and motivates Menke's intervention is that law is both the opposite of violence (and the medium though which cycles of vengeance, of repaying violence with violence, is brought to a close) and, at the same time, a form of violence, not merely instrumentally as a mode of action that utilizes coercion, but structurally as the necessary 
imposition of a normative order which integrates spatial, temporal, material and subjective boundaries concerning who can or cannot do what, where, when and how.

The essay develops its engagement with the paradox of law in two stages. The first part - "The Fate of Law" - shows why, and in what precise sense, the law is irreducibly characterized by structural violence. The second part - "The Relief [Entsetzung] of Law" - explores the possibility of law becoming self-reflectively aware of its own violence and, hence, of the form of a self-critique of law in view of its own violence. In both parts, the essay's philosophical claims are developed through analyses of works of drama: two classical tragedies in the first part (Aeschylus' Oresteia and Sophocles' King Oedipus), and two modern dramas in the second part (Heinrich von Kleist's The Broken Jug and Heiner Müller's Volokolamsk Highway I). The essay thus attempts to illuminate the paradoxical nature of law by way of a philosophical interpretation of literature. It does so on the grounds that whereas philosophical discourses on law are typically either discourses of legitimization or of critique of law, in that such discourses are almost ineluctably drawn to take up a stand towards law on the question of its violence, literary texts need take no such stand and hence are able to be much more sensitive to the internal duplicity of law, to dwell on rather than to attempt to deny or overcome its paradoxical character. By taking this literary route in his philosophical analysis, Menke aims to draw out the possibility and form of a relation of law to itself that acknowledges its structural violence and hence opens itself to the question of whether and when the enforcement of law is required; that is, rather than taking its enforcement to be necessary, it resituates enforcement as open to judgment.

Menke's essay is both rich and deep, and the responses from interlocutors as well as his reply to these responses draw out and develop the dimensions of his analysis in ways that further illuminate its importance as a reflection on the paradox of law. 
Christoph Menke - 9781526105097

Downloaded from manchesterhive.com at 04/26/2023 01:52: 08PM

via free access 